\title{
New mixed ligand complexes of ruthenium(II) that incorporate a modified phenanthroline ligand: Synthesis, spectral characterization and DNA binding
}

\author{
S MURALI, C V SASTRI and BHASKAR G MAIYA* \\ School of Chemistry, University of Hyderabad, Hyderabad 500 046, India \\ e-mail:bgmsc@uohyd.ernet.in
}

\begin{abstract}
The hexafluorophosphate and chloride salts of two ruthenium(II) complexes, viz. $\left[\operatorname{Ru}(\text { phen })(\text { ptzo })_{2}\right]^{2+}$ and $\left[\operatorname{Ru}(\text { ptzo })_{3}\right]^{2+}$, where ptzo $=1,10-$ phenanthrolino[5,6-e]1,2,4-triazine-3-one (ptzo) - a new modified phenanthroline (phen) ligand, have been synthesised. These complexes have been characterised by infrared, UV-Vis, steady-state emission and ${ }^{1} \mathrm{H}$ NMR spectroscopic methods. Results of absorption and fluorescence titration as well as thermal denaturation studies reveal that both the bis-and tris-complexes of ptzo show moderately strong affinity for binding with calf thymus (CT) DNA with the binding constants being close to $10^{5} \mathrm{M}^{-1}$ in each case. An intercalative mode of DNA binding has been suggested for both the complexes. Emission studies carried out in non-aqueous solvents and in aqueous media without DNA reveal that both $\left[\mathrm{Ru}(\text { phen })(\mathrm{ptzo})_{2}\right]^{2+}$ and $\left[\mathrm{Ru}(\mathrm{ptzo})_{3}\right]^{2+}$ are weakly luminescent under these solution conditions. Successive addition of CT DNA to buffered aqueous solutions containing $\left[\mathrm{Ru}(\mathrm{phen})(\mathrm{ptzo})_{2}\right]^{2+}$ results in an enhancement of the emission. These results have been discussed in the light of the dependence of the structure-specific deactivation processes of the MLCT state of the metallointercalator with the characteristic features of its DNA interaction. In doing so, attempts have been made to compare and contrast its properties with those of the analogous phenanthroline-based complexes including the ones reported by us previously.
\end{abstract}

Keywords. Ruthenium(II) complexes; modified phenanthroline ligand; spectroscopy; DNA binding; fluorescence enhancement.

\section{Introduction}

A major current research interest in bioinorganic chemistry concerns binding and cleavage of DNA by metal complexes, and it is related to the utility of these complexes in the design and development of synthetic restriction enzymes, new drugs, DNA foot printing agents etc ${ }^{1-8}$. Metal complexes have been found to be particularly useful for the above-mentioned purposes because of their potential to bind DNA via multitude of interactions and to cleave the duplex by virtue of their intrinsic chemical, electrochemical and photochemical reactivities. Presently, a great deal of attention is centred around DNA interactions of mixed ligand complexes that contain both phen (phen $=1,10$-phenanthroline) and modified phen ligands, the latter of which so designed to augment the intercalative interaction by the complexes ${ }^{3,7-14}$. A singular advantage in using these metallointercalators for such studies is that the ligands or the metal in them can be varied

*For correspondence 
in an easily controlled manner to facilitate an individual application. We have recently reported the synthesis, characterisation and DNA binding and cleavage proclivities of a series of complexes incorporating modified phen ligands. The architecture of our ligands is such that they are extended aromatic systems and also possess electron withdrawing substituents such as quinone, cyano groups etc. in their $\pi$ frame work ${ }^{15-18}$. Such structural features were intentionally incorporated in these ligands not only to ensure strong intercalative DNA binding but also to effect efficient DNA photocleavage by the ensuing complexes. More recently, we have been able to design and synthesise a new generation of such modified phen ligands the structures of which are shown in figure 1 . This paper deals with the synthesis, spectral characterisation and DNA binding properties of two ruthenium(II) complexes that incorporate a representative new generation modified phen ligand, viz. 1,10-phenanthrolino[5,6-e]1,2,4-triazine-3-one (ptzo). Structures of the two investigated complexes, $\left[\mathrm{Ru}(\mathrm{phen})(\mathrm{ptzo})_{2}\right]^{2+}$ and $\left[\mathrm{Ru}(\mathrm{ptzo})_{3}\right]^{2+}$, are given in figure 2 .

\section{Experimental}

\subsection{Materials}

The common chemicals and solvents utilized in this study were purchased from E. Merck (India) and the fine chemicals were procured from Aldrich Chemical Co. (USA). Calfthymus (CT) DNA and tetrabutylammonium chloride ( $\mathrm{TBACl})$ were obtained from Sigma Chemicals (USA). All the solvents were purified before use as per the standard procedures ${ }^{19}$. Deionised, triply distilled water was used for preparing various buffers.

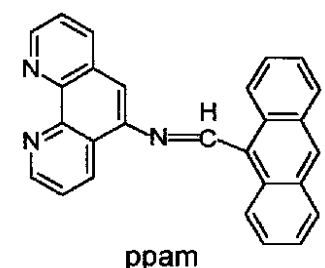

ppam<smiles>C(=N/c1cc2cccnc2c2ncccc12)\c1ccc2ccc3cccc4ccc1c2c34</smiles>

ppym

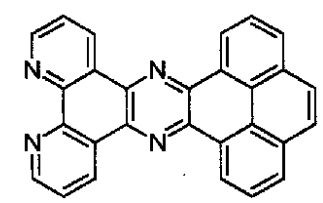

pdp

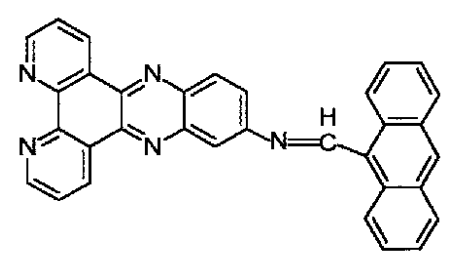

dpam

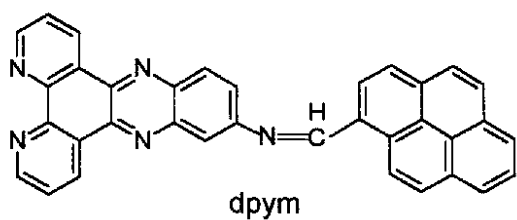

dpym

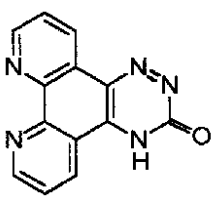

ptzo

Figure 1. Structures of the new generation DNA-binding ligands. 


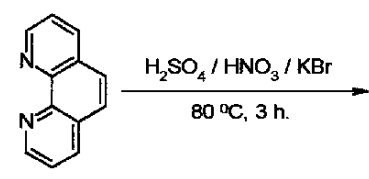

phen

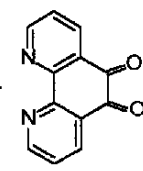

phen-dione
$\mathrm{H}_{2} \mathrm{~N}-\mathrm{NH}-\mathrm{CO}-\mathrm{NH}_{2}$

$\mathrm{CH}_{3} \mathrm{OH}$, Reflux, $4 \mathrm{~h}$.

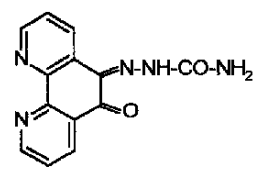

psc
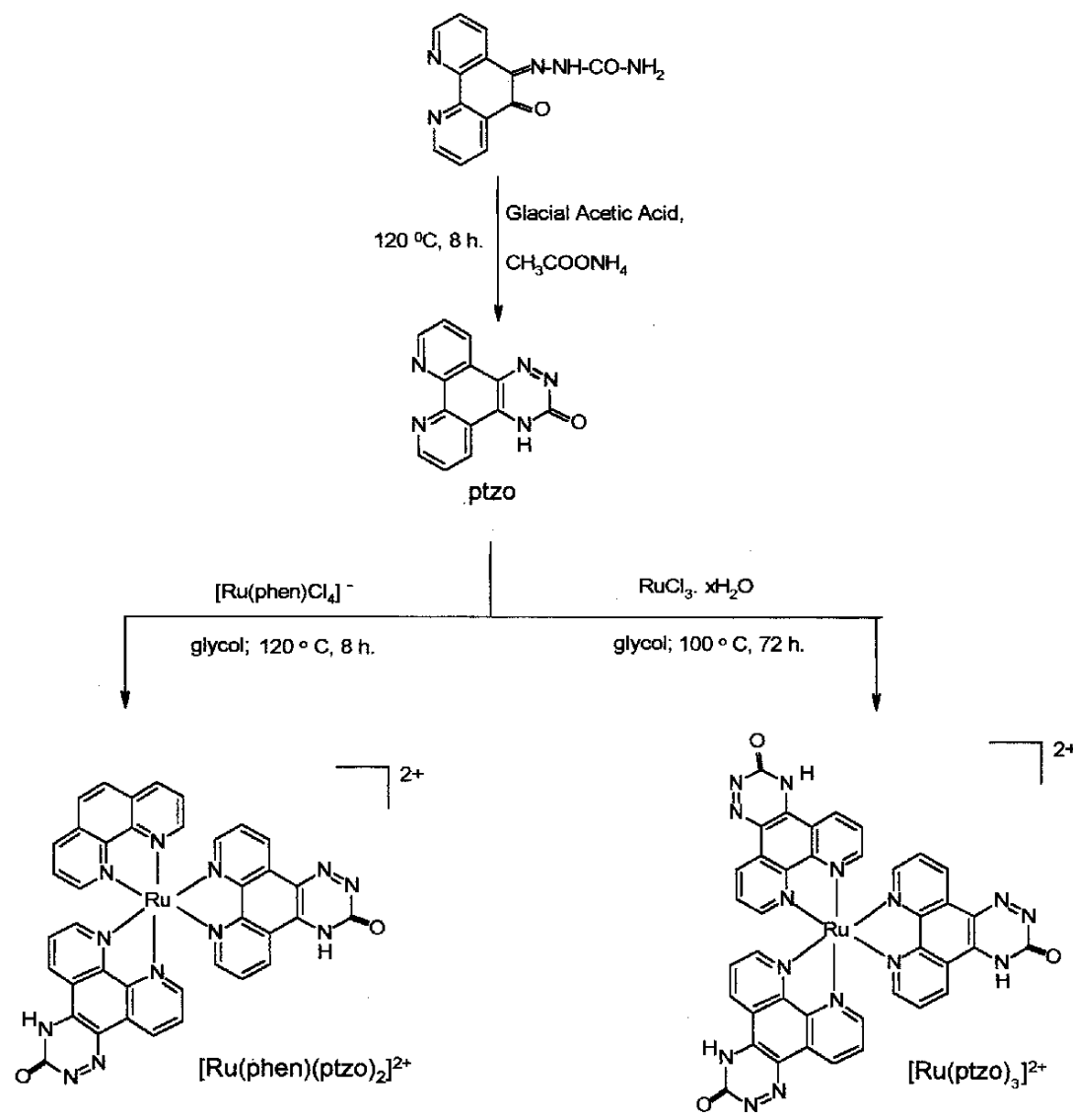

Figure 2. Scheme leading to synthesis of the two new ruthenium(II) complexes investigated during this study.

1,10-Phenanthroline-5,6-dione (phen-dione) and $\left[\mathrm{Ru}(\mathrm{phen}) \mathrm{Cl}_{4}\right]^{-}$were synthesised by the reported procedures ${ }^{20,21}$. Syntheses of ptzo $^{22}$ and its ruthenium(II) complexes investigated in this study are detailed below.

2.1a 1,10-Phenanthrolino[5,6-e]1,2,4-triazine-3-one

(ptzo): Phen-dione

$(0 \cdot 50 \mathrm{~g}$, $2.40 \mathrm{mmol})$ and semicarbazide hydrochloride $(0.29 \mathrm{~g}, 2.60 \mathrm{mmol})$ were dissolved in $30 \mathrm{ml}$ of methanol under heating, and the solution was refluxed for $3 \mathrm{~h}$. The solvent was reduced to half its volume and the yellow solid product, 1,10-phenanthroline-5,6-dionesemicarbazone (psc), obtained was filtered by suction. Yield $=0.49 \mathrm{~g}(77 \%)$.

The semicarbazone $(2.84 \mathrm{~g}, 10.70 \mathrm{mmol})$ obtained above was dissolved in $7 \mathrm{ml}$ of acetic acid and an excess $(5 \mathrm{~g})$ of ammonium acetate was added. The mixture was heated 
at $120^{\circ} \mathrm{C}$ for $8 \mathrm{~h}$ and then cooled. The greenish yellow solid was collected by filtration, washed several times with water until the acetic acid was removed. Yield $=0.50 \mathrm{~g}(19 \%)$.

$2.1 \mathrm{~b}\left[\mathrm{Ru}(\right.$ phen $)\left(\right.$ ptzo $\left._{2}\right]\left(\mathrm{PF}_{6}\right)_{2}: \mathrm{A}$ mixture containing $\left[\mathrm{Ru}(\mathrm{phen}) \mathrm{Cl}_{4}\right]^{-} \quad(0.44 \mathrm{~g}$, $1.02 \mathrm{mmol})$, ptzo $(0.15 \mathrm{~g}, 0.60 \mathrm{mmol})$ and glycol $(25 \mathrm{ml})$ was heated at $90-100^{\circ} \mathrm{C}$ under the nitrogen atmosphere for $5 \mathrm{~h}$ to give a dark red solution. The solution was cooled to the room temperature and was diluted with $30 \mathrm{ml}$ of water. Saturated aqueous $\mathrm{NH}_{4} \mathrm{PF}_{6}$ solution was added (dropwise) and the precipitated product was collected by filtration. It was purified by recrystallisation (acetone-ether) and dried in vacuum. Yield $=0.36 \mathrm{~g}$ $(33 \%)$.

2.1c $\left[R u(p t z o)_{3}\right]\left(P F_{6}\right)_{2}:$ A mixture of $\mathrm{RuCl}_{3} .3 \mathrm{H}_{2} \mathrm{O}(0.08 \mathrm{~g}, 0.37 \mathrm{mmol})$, ptzo $(0.50 \mathrm{~g}$, $2.22 \mathrm{mmol})$ and glycol $(25 \mathrm{ml})$ was heated at $90-100^{\circ} \mathrm{C}$ under the nitrogen atmosphere for $72 \mathrm{~h}$ to give a dark red solution. The solution was cooled to the room temperature and was diluted with $30 \mathrm{ml}$ of water and then saturated aqueous $\mathrm{NH}_{4} \mathrm{PF}_{6}$ solution was added dropwise. The precipitated product was collected by filtration, purified by recrystallisation (acetone-ether) and dried in vacuum. Yield $=0.08 \mathrm{~g}(18 \%)$.

The water soluble chloride salts needed for the DNA studies were obtained by dissolving the above hexafluorophosphate salts in minimum amount of acetone and adding a saturated solution of $\mathrm{TBACl}$ in acetone (dropwise) until the precipitation was complete. The chloride salts were filtered, washed thoroughly with acetone and vacuum dried. Conversion was close to $90 \%$ of the theoretical yield in each case.

\subsection{Physical methods}

The infrared spectra were recorded on a Jasco Model 5300 FT-IR spectrophotometer. The spectrum of the solid samples were recorded by dispersing the samples in $\mathrm{KBr}$ pellets. The ${ }^{1}$ HNMR spectra were recorded on a Bruker NR-200 AF-FT NMR spectrophotometer using $\mathrm{CDCl}_{3}$ or DMSO- $d_{6}$ as the solvent. Tetramethysilane (TMS) was used as the internal standard.

The UV-Vis spectra were recorded with either a Shimadzu model UV-3101 PC or a Shimadzu model UV-160A spectrophotometer. A matched pair of quartz cuvettes were employed for this purpose. Steady-state emission spectra were recorded on a Fluoromax3 spectrophotometer using a quartz cell. Detection of emission was done at right angles to the excitation wavelength. The excitation and emission slit widths employed were $5 \mathrm{~nm}$ each. For recording the emission spectra, optical densities of the samples were adjusted to about 0.2 at the excitation wavelength. Emission quantum yields $(\phi)$ were calculated by integrating the area under the fluorescence curves and by using the formula

$$
\phi_{\text {sample }}=\frac{\mathrm{OD}_{\text {standard }} \times A_{\text {sample }}}{\mathrm{OD}_{\text {sample }} \times A_{\text {standard }}} \times \phi_{\text {standard }}
$$

where OD is optical density of the compound at the excitation wavelength $(450 \mathrm{~nm})$ and $A$ is the area under the emission spectral curve. The standard used for the fluorescence quantum yield measurements was $\left[\mathrm{Ru}(\text { phen })_{3}\right]^{2+}\left(\phi=0.028 \text { in } \mathrm{CH}_{3} \mathrm{CN}\right)^{23}$. Refractive index corrections have been incorporated while reporting the fluorescence data in various solvents ${ }^{24}$. 


\subsection{DNA binding experiments}

CT DNA was used for binding with chloride salts of the complexes investigated during this work. The stock solution was made by dissolving CT DNA in appropriate buffers and kept overnight at $4^{\circ} \mathrm{C}$ to ensure complete dissolution. The concentration of DNA (nucleotide phosphate) was measured by using its known extinction coefficient at $260 \mathrm{~nm}$ $\left(6600 \mathrm{M}^{-1} \mathrm{~cm}^{-1}\right)^{25}$

2.3a Absorption titration: Absorption titration experiments ( $5 \mathrm{mM}$ Tris, $50 \mathrm{mM} \mathrm{NaCl}$, $p \mathrm{H}$ 7.0) were performed by using a fixed metal complex concentration to which increments of the stock DNA solutions (containing the same concentration of the metal complex) were added. Typical concentration of the metal complex used was $20-30 \mu \mathrm{M}$ and that of DNA ranged between 0 and 100 or more equivalents (base pairs). After the addition of DNA to metal complex, the resulting solution was allowed to equilibrate for $5-10 \mathrm{~min}$ at $25^{\circ} \mathrm{C}$. The absorption readings (corresponding to the changes at maximum absorption) were noted. The data were then fit to the following equation to obtain the intrinsic binding constant, $K_{b}$.

$$
[\mathrm{DNA}] /\left(\varepsilon_{a}-\varepsilon_{f}\right)=[\mathrm{DNA}] /\left(\varepsilon_{b}-\varepsilon_{f}\right)+1 / K_{b}\left(\varepsilon_{b}-\varepsilon_{f}\right)
$$

where $\varepsilon_{a}, \varepsilon_{f}$, and $\varepsilon_{b}$ are the apparent, free and bound metal complex extinction coefficients respectively. A plot of [DNA]/( $\left.\varepsilon_{a}-\varepsilon_{f}\right)$ vs [DNA] gave a slope of $1 /\left(\boldsymbol{\varepsilon}_{b}-\boldsymbol{\varepsilon}_{f}\right)$ and a $y$-intercept equal to $K_{b} /\left(\varepsilon_{b}-\varepsilon_{f}\right) ; K_{b}$ is the ratio of slope to $y$-intercept ${ }^{26}$.

2.3b Luminescence titration: These experiments ( $5 \mathrm{mM}$ Tris, $50 \mathrm{mM} \mathrm{NaCl}, p \mathrm{H} 7 \cdot 0$ ) were performed by using a fixed metal complex concentration to which increments of the stock DNA solutions (containing the same concentration of the metal complex) were added. Typical concentration of the metal complex used was $10-12 \mu \mathrm{M}$ and that of DNA ranged between 0 and 100 or more equivalents (base pairs). After the addition of DNA to metal complex, the resulting solution was allowed to equilibrate for $5-10 \mathrm{~min}$ at $25^{\circ} \mathrm{C}$ before being excited by $450 \mathrm{~nm}$ light. The data obtained were analysed using equation.

$$
C_{F}=C_{T}\left[\left(I / I_{0}\right)-P\right] /[1-P],
$$

where, $C_{T}$ is concentration of the probe (complex) added, $C_{F}$ is the concentration of the free probe, and $I_{0}$ and $I$ are its emission intensities in the absence and in the presence of DNA, respectively. $P$ is the ratio of the observed emission quantum yield of the bound probe to the free probe. The value of $P$ was obtained from a plot of $I / I_{0}$ vs $1 /[\mathrm{DNA}]$ such that the limiting emission yield is given by the $y$-intercept. The amount of bound probe $\left(C_{B}\right)$ at any concentration was equal to $C_{T}-C_{F}$. A plot of $r / C_{F}$ vs $r\left(=C_{B} /[\mathrm{DNA}]\right)$ gave the binding isotherm, and the best fit of the data resulted in the binding constant, $K_{b}{ }^{27}$.

2.3c Thermal denaturation: Thermal denaturation experiments were performed using a Shimadzu model UV-160A spectrophotometer coupled with a temperature controller model TCC-240 A. The buffer used was $1 \mathrm{mM}$ phosphate, $2 \mathrm{mM} \mathrm{NaCl}, p \mathrm{H} \mathrm{7 \cdot 0.}$ Absorption values at $260 \mathrm{~nm}$ for the CT DNA $(150 \mu \mathrm{M}$ nucleotide phosphate) were monitored at various temperatures. The melting temperature $\left(T_{m}\right)$ is defined as the temperature at which $50 \%$ of double strand becomes single stranded and $\sigma_{T}$, the curve 
width, is the temperature range between which $10 \%$ and $90 \%$ of the absorption increase occurs. The $T_{m}$ of CT DNA and $\sigma_{\mathrm{T}}$ were found to be $61 \pm 1^{\circ} \mathrm{C}$ and $20 \pm 1^{\circ}$ respectively, under the experimental conditions employed in this study. The $T_{m}$ and $\sigma_{T}$ values were measured for [DNA nucleotide phosphate]/[complex] $=25$ upon adding equal concentrations of the complex to both the reference and the sample cuvettes.

\section{Results and discussion}

\subsection{Spectral characterisation}

The scheme leading to synthesis of the new ligand and the mixed-ligand ruthenium(II) complexes is shown in figure 2. 1,10-Phenanthroline-5,6-dione (phen-dione) was prepared by the reported procedure ${ }^{20}$. 1,10-Phenanthrolino[5,6-e]1,2,4-triazine-3-one (ptzo) was prepared in two steps. In the first step, refluxing phen-dione with semicarbazide hydrochloride in methanol gave high yield (77\%) of 1,10-phenanthroline5,6-dione-semicarbazone (psc). The product psc was precipitated out on concentrating the reaction mixture and was filtered hot and dried under vacuum. Next, the ring closure reaction was carried out by refluxing psc in glacial acetic acid in the presence of excess ammonium acetate. The new ligand ptzo was isolated, albeit in low (19\%) yield. The mixed ligand complex $\left[\mathrm{Ru}(\mathrm{phen})(\mathrm{ptzo})_{2}\right]^{2+}$ was prepared by refluxing appropriate mole ratio of $\left[\mathrm{Ru}(\mathrm{phen}) \mathrm{Cl}_{4}\right]^{-}$and ptzo in ethylene glycol. The tris-ruthenium(II) complex, $\left[\mathrm{Ru}(\mathrm{ptzo})_{3}\right]^{2+}$, was prepared by heating ruthenium tricholide and six fold molar excess of ptzo under an inert atmosphere at $100^{\circ} \mathrm{C}$. The complexes thus prepared were recystallised from acetone-ether mixture. Both the complexes were obtained in low yields.

All the compounds synthesised during this study have been characterised by infrared, UV-Vis, emission and ${ }^{1} \mathrm{H}$ NMR spectroscopic methods. The important stretching frequencies observed in the infrared spectra are listed in table 1. A strong peak at $1721 \mathrm{~cm}^{-1}$ is due to the carbonyl stretching frequency in psc and it was seen to be shifted to $1686 \mathrm{~cm}^{-1}$ in ptzo and to $1676 \mathrm{~cm}^{-1}$ in both $\left[\mathrm{Ru}(\mathrm{phen})(\mathrm{ptzo})_{2}\right]\left(\mathrm{PF}_{6}\right)_{2}$ and $\left[\mathrm{Ru}(\mathrm{ptzo})_{3}\right]\left(\mathrm{PF}_{6}\right)_{2}$. The infrared spectra of the two chloride complexes were quite similar to the corresponding hexafluorophosphate analogues except that the strong peaks present at $839 / 844 \mathrm{~cm}^{-1}$ due to the $\mathrm{PF}_{6}$ group are missing in the former complexes.

UV-Vis data of all the compounds synthesised during this study are summarised in table 1. Ligand ptzo shows two moderately intense $\pi-\pi^{*}$ bands centered at 373,319 and $259 \mathrm{~nm}$ in $\mathrm{CH}_{3} \mathrm{CN}$ containing a drop of $\mathrm{HCl}$ (acid was added to ensure complete

Table 1. Infrared and UV-Vis spectral data.

\begin{tabular}{llc}
\hline Compound & \multicolumn{1}{c}{$\bar{v}\left(\mathrm{~cm}^{-1}\right)^{\mathrm{a}}$} & $\lambda_{\max }(\log \varepsilon)^{\mathrm{b}}$ \\
\hline phen-dione & $1684,1559,1458$ & $304(3 \cdot 64), 260(3 \cdot 81), 232(3 \cdot 81)$ \\
psc & $3351,3142,1721,1632,1597$ & $366(3 \cdot 03), 255(4 \cdot 43), 212(3 \cdot 99)$ \\
ptzo $^{\mathrm{c}}$ & $2982,1686,1582$ & $374(3 \cdot 64), 319(4 \cdot 28), 259(4 \cdot 79)$ \\
{$\left[\mathrm{Ru}(\right.$ phen $)\left(\mathrm{ptzo}_{2}\right]\left(\mathrm{PF}_{6}\right)_{2}$} & $3443,1676,1564,839$ & $424(4 \cdot 26), 378(4 \cdot 19), 296(4 \cdot 60)$, \\
& & $263(5 \cdot 01), 219(4 \cdot 84)$ \\
{$\left[\mathrm{Ru}(\text { ptzo })_{3}\right]\left(\mathrm{PF}_{6}\right)_{2}$} & $3400,1676,1564,844$ & $426(4 \cdot 17), 377(4 \cdot 18), 260(4 \cdot 86)$, \\
& & $220(4 \cdot 76)$
\end{tabular}

\footnotetext{
${ }^{\mathrm{a}} \mathrm{As} \mathrm{KBr}$ pellets; ${ }^{\mathrm{b}}$ as $\mathrm{CH}_{3} \mathrm{CN}$; error limits: $\lambda_{\max }, \pm 1 \mathrm{~nm}$; $\log \varepsilon, \pm 10 \%$; ${ }^{\mathrm{c}}$ spectra $(\lambda>250 \mathrm{~nm})$ were
} recorded after adding a drop of dil. $\mathrm{HCl}$ to the $\mathrm{CH}_{3} \mathrm{CN}$ solution 
solubility). In the UV-Vis spectra of both the complexes, the ultraviolet region of the absorption shows intense bands arising from the $\pi-\pi^{*}$ transitions of coordinated phen and ptzo. These bands appear at 378, 296, 263 and $219 \mathrm{~nm}$ for $\left[\mathrm{Ru}(\mathrm{phen})(\mathrm{ptzo})_{2}\right]\left(\mathrm{PF}_{6}\right)_{2}$ and at 377,260 and $220 \mathrm{~nm}$ for $\left[\mathrm{Ru}(\mathrm{ptzo})_{3}\right]\left(\mathrm{PF}_{6}\right)_{2}$, figure 3 . The peak at $\sim 220 \mathrm{~nm}$ in both the new complexes is also seen in the case of $\left[\mathrm{Ru}(\mathrm{phen})_{3}\right]^{2+}$ and hence is ascribable to either phen or 'phen' part of ptzo ligand/s present in these complexes. The other peaks are thus ascribable either exclusively to the transitions involving coordinated ptzo $(>260 \mathrm{~nm})$ or to both phen and ptzo (peak at $\sim 260 \mathrm{~nm})$. $\left[\operatorname{Ru}(\text { phen })(\mathrm{ptzo})_{2}\right]^{2+}$ and $\left[\mathrm{Ru}(\mathrm{ptzo})_{3}\right]^{2+}$ are additionally characterised by the presence of broad $\mathrm{d} \pi-\pi^{*}$ MLCT transition bands at $424 \mathrm{~nm}$ and $426 \mathrm{~nm}$ respectively, typical of any ruthenium(II)polypyridyl complex. The $\lambda_{\max }$ and $\log \varepsilon$ values of the chloride derivatives of both $\left[\mathrm{Ru}(\mathrm{phen})(\mathrm{ptzo})_{2}\right]^{2+}$ and $\left[\mathrm{Ru}(\mathrm{ptzo})_{3}\right]^{2+}$ are found to be close to those of the corresponding $\mathrm{PF}_{6}$ salts.

The UV-Vis data of the $\mathrm{PF}_{6}$ salts of $\left[\mathrm{Ru}(\mathrm{phen})(\mathrm{ptzo})_{2}\right]^{2+}$ and $\left[\mathrm{Ru}(\mathrm{ptzo})_{3}\right]^{2+}$ in various solvents are given in tables 2 and 3, respectively. These data reveal that the MLCT peak maxima vary by as much as $36 \mathrm{~nm}$ for $\left[\mathrm{Ru}(\mathrm{phen})(\mathrm{ptzo})_{2}\right]^{2+}$ (compare $\lambda_{\max }$ values in $\mathrm{CH}_{3} \mathrm{CN}$ and dimethylformamide in table 2). The corresponding solvent dependent shift in the MLCT band for $\left[\mathrm{Ru}(\mathrm{ptzo})_{3}\right]^{2+}$ is $25 \mathrm{~nm}$ (compare data in THF and methanol in table 3 ). However, no obvious correlation exists between the $\lambda_{\max }$ and the dielectric constant (or $E T_{30}$ ) values for these MLCT transitions suggesting that other specific solvation features (such as for example, H-bonding of the ptzo ligand with the solvent) might be responsible for this. A similar nonlinearity was also observed for the plots of emission peak energies vs. solvent dielectric constant (or $E T_{30}$ values), as described below.

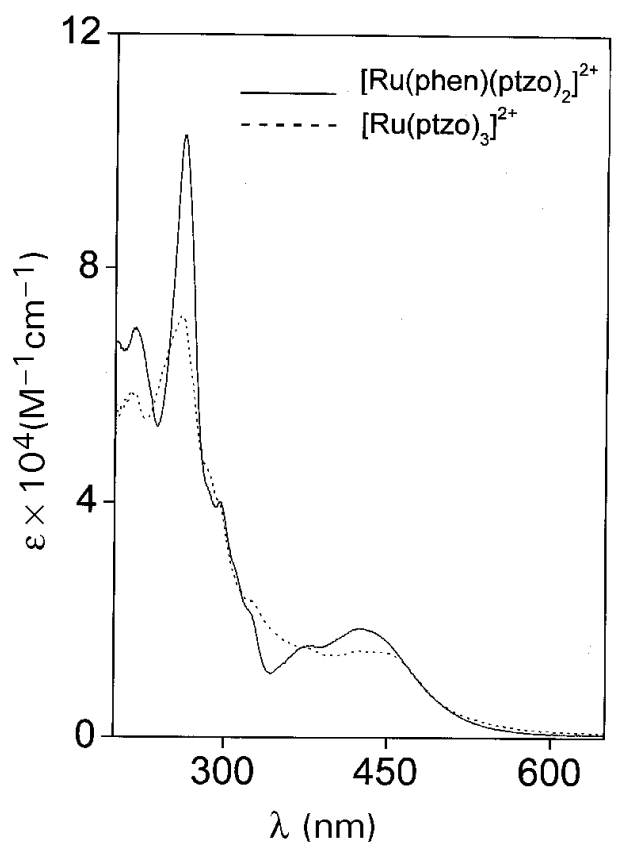

Figure 3. UV-Vis spectra of $\left[\mathrm{Ru}(\mathrm{phen})(\mathrm{ptzo})_{2}\right]\left(\mathrm{PF}_{6}\right)_{2}$ and $\left[\mathrm{Ru}(\mathrm{ptzo})_{3}\right]\left(\mathrm{PF}_{6}\right)_{2}$ in $\mathrm{CH}_{3} \mathrm{CN}$. 
Table 2. Absorption and emission $\left(\lambda_{\mathrm{ex}}=450 \mathrm{~nm}\right)$ spectral data for $\left[\mathrm{Ru}(\mathrm{phen})\left(\mathrm{ptzo}_{2}\right]\left(\mathrm{PF}_{6}\right)_{2}\right.$ in various solvents ${ }^{\mathrm{a}}$.

\begin{tabular}{|c|c|c|}
\hline Solvent & Absorption $\lambda_{\max } n m(\log \varepsilon)$ & Emission $\lambda_{\mathrm{em}} \mathrm{nm}(\phi)$ \\
\hline Dicholoromethane & $428(4.30), 297(4.63), 264(5.03), 235(4.74)$ & $622,696(0 \cdot 0035)$ \\
\hline Dioxane & $455(4.32), 252(4.76), 212(5.63)$ & $643(0.0014)$ \\
\hline Tetrahydrofuran & $433(4.38), 384(4.32), 265(5.02), 226(4.85)$ & $678(0 \cdot 0015)$ \\
\hline Acetonitrile & $\begin{array}{l}424(4 \cdot 26), 378(4 \cdot 19), 296(4 \cdot 60), 263(5 \cdot 01) \text {, } \\
\quad 219(4 \cdot 84)\end{array}$ & $636(0 \cdot 0028)$ \\
\hline Isopropanol & $\begin{array}{l}446(4 \cdot 38), 393(4 \cdot 30), 382(4 \cdot 30), 265(5 \cdot 03), \\
\quad 224(4 \cdot 90)\end{array}$ & $643(0 \cdot 0027)$ \\
\hline Methanol & 450 (4.39), 381 (4.32), $264(4.97), 229$ (4.90) & $608(0 \cdot 0026)$ \\
\hline Dimethylformamide & $\begin{array}{l}460(4.42), 429(4 \cdot 39), 344(4.53), 288(4.79), \\
\quad 267(4.90)\end{array}$ & $620,682(0 \cdot 0023)$ \\
\hline
\end{tabular}

${ }^{\mathrm{a}}$ Error limits: $\lambda, \pm 1 \mathrm{~nm} ; \log \varepsilon, \pm 10 \% ; \phi, \pm 12 \%$

Table 3. Absorption and emission $\left(\lambda_{\mathrm{ex}}=450 \mathrm{~nm}\right)$ spectral data for $\left[\mathrm{Ru}(\mathrm{ptzo})_{3}\right]\left(\mathrm{PF}_{6}\right)_{2}$ in various solvents ${ }^{\mathrm{a}}$.

\begin{tabular}{lcc}
\hline Solvent & \multicolumn{1}{c}{ Absorption $\lambda_{\max } \mathrm{nm}(\log \varepsilon)$} & Emission $\lambda_{\mathrm{em}} \mathrm{nm}(\phi)$ \\
\hline Dicholoromethane & $427(4 \cdot 30), 297(4 \cdot 73), 264(5 \cdot 03), 235(4 \cdot 81)$ & $599(0 \cdot 0015)$ \\
Dioxane & $426(4 \cdot 16), 373(4 \cdot 17), 360(4 \cdot 15), 263(4 \cdot 85)$ & $617(0 \cdot 0003)$ \\
Tetrahydrofuran & $424(4 \cdot 20), 372(4 \cdot 21), 265(4 \cdot 89), 226(4 \cdot 81)$ & $636(0 \cdot 0008)$ \\
Acetonitrile & $426(4 \cdot 17), 377(4 \cdot 18), 260(4 \cdot 86), 220(4 \cdot 76)$ & $618(0 \cdot 0024)$ \\
Isopropanol & $443(4 \cdot 22), 423(4 \cdot 23), 378(4 \cdot 23), 262(4 \cdot 90)$ & $607(0 \cdot 0010)$ \\
Methanol & $449(4 \cdot 32), 378(4 \cdot 34), 264(4 \cdot 95), 241(4 \cdot 96)$ & $606(0.0031)$ \\
Dimethylformamide & $429(4 \cdot 31), 341(4 \cdot 54), 287(4 \cdot 79), 257(4 \cdot 87)$ & $520,607(0 \cdot 0033)$ \\
\hline
\end{tabular}

${ }^{a}$ Error limits: $\lambda, \pm 1 \mathrm{~nm} ; \log \varepsilon, \pm 10 \% ; \phi, \pm 12 \%$

Both psc and ptzo were non-emittive under our experimental conditions but the $\mathrm{PF}_{6}$ salts of the ruthenium(II) complexes of ptzo were found to emit light when excited into their respective MLCT band maxima in non-aqueous media. Luminescence data for $\left[\mathrm{Ru}(\mathrm{phen})(\mathrm{ptzo})_{2}\right]^{2+}$ and $\left[\mathrm{Ru}(\mathrm{ptzo})_{3}\right]^{2+}$ recorded in various organic solvents are summarized in tables 2 and 3 , respectively. The corresponding spectra for $\left[\mathrm{Ru}(\mathrm{phen})(\mathrm{ptzo})_{2}\right]^{2+}$ are given in figure 4 along with the plots of emission energy vs. solvent dielectric constant $(\varepsilon)$ or $E T_{30}$ values. Similar results were obtained for $\left[\mathrm{Ru}(\mathrm{ptzo})_{3}\right]^{2+}$. The luminescence data given in tables 2 and 3 and the analyses as illustrated in figure 4, suggest that no definite conclusions could be established with regard to the effect of solvent on the emission peak maxima of these complexes. Thus, it appears that the solvent dependency of both the absorption and emission peak energies are complicated and the peak shifts are consequence of several factors including charge transfer nature of the bands, specific H-bonding interactions involving the coordinated ptzo etc.

The emission quantum yields of $\left[\mathrm{Ru}(\mathrm{phen})(\mathrm{ptzo})_{2}\right]^{2+}$ and $\left[\mathrm{Ru}(\mathrm{ptzo})_{3}\right]^{2+}$ also vary with the solvents (see tables 2 and 3). Again, there seems to be no well-defined variation of $\phi$ with respect to polarity of the solvent but, it was noticed that the values for $\left[\mathrm{Ru}(\mathrm{phen})(\mathrm{ptzo})_{2}\right]^{2+}$ and $\left[\mathrm{Ru}(\mathrm{ptzo})_{3}\right]^{2+}$ are invariably lower than that due to $\left[\mathrm{Ru}(\mathrm{phen})_{3}\right]^{2+}$ in each solvent. 

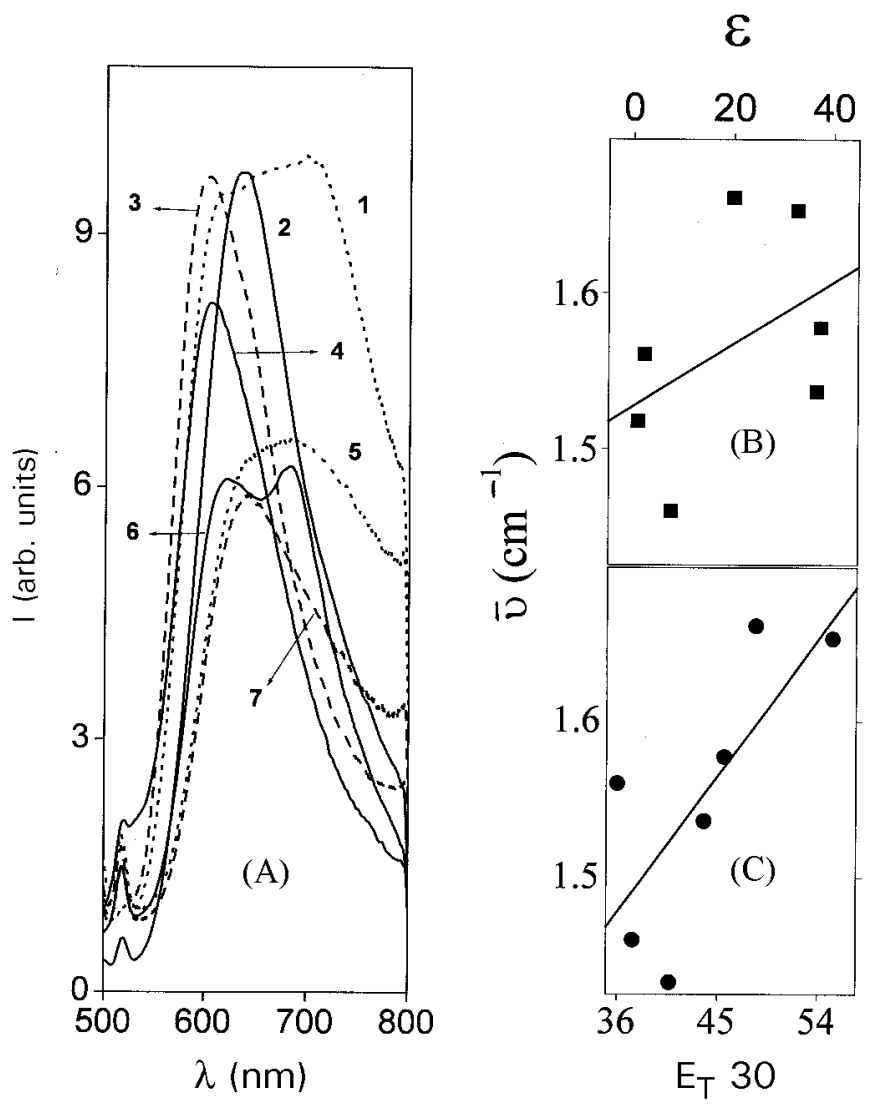

Figure 4. (A) Luminescence spectra of $\left[\mathrm{Ru}(\mathrm{phen})(\mathrm{ptzo})_{2}\right]\left(\mathrm{PF}_{6}\right)_{2}$ in various solvents. Legend: (1) $\mathrm{CH}_{2} \mathrm{Cl}_{2}$ (2) $\mathrm{CH}_{3} \mathrm{CN}$ (3) 2-propanol (4) $\mathrm{CH}_{3} \mathrm{OH}$ (5) THF (6) DMF and (7) dioxane. (B) and (C) are the plots of emission energy vs dielectric constant (ह) and $E T_{30}$ values of the solvents, respectively.

The ${ }^{1} \mathrm{H}$ NMR spectra of psc and ptzo and also those of the ruthenium(II) complexes of ptzo are summarised in table 4 . The spectra are highly characteristic and the resonance positions as well as the corresponding intensities of the signals arising from various protons in these compounds are in conformity with the proposed structures. For psc, the $\mathrm{NH}$ peak is seen at $13.67 \mathrm{ppm}$ and the broad peak at $\sim 4.50 \mathrm{ppm}$ corresponds to the $\mathrm{NH}_{2}$ protons. The protons on the phen moiety of psc are observed at a more downfield region when compared to the corresponding protons of phen-dione. Cyclization of psc results in further splitting of the protons on the phen moiety in ptzo. The two protons nearer to the donor nitrogen atoms (positions 1 and 10 ) appear together as a multiplet at $8.83 \mathrm{ppm}$. The two protons farthest from these nitrogen atoms appear differently at $8.74 \mathrm{ppm}(d)$ and at $9.13 \mathrm{ppm}(d)$. The remaining two protons have also lost their equivalence when compared to phen-dione and appear as multiplets at $7.74 \mathrm{ppm}$ and $7.95 \mathrm{ppm}$. Comparison of the NMR spectrum of $\left[\operatorname{Ru}(\text { phen })(\text { ptzo })_{2}\right]^{2+}$ and $\left[R u(p t z o)_{3}\right]^{2+}$ with those of phen, ptzo and $\left[\mathrm{Ru}(\mathrm{phen})_{3}\right]^{2+}$ reveals that resonances due to protons of both phen and ptzo are considerably broadened and also shifted indicating complexation. 
Table 4. ${ }^{1} \mathrm{H}$ NMR spectral data.

\begin{tabular}{|c|c|}
\hline Compound & $\delta$, ppm \\
\hline phen-dione $^{\mathrm{a}}$ & $9.12(d d, 2 \mathrm{H}), 8.51(d d, 2 \mathrm{H}), 7.55(m, 2 \mathrm{H})$ \\
\hline $\mathrm{psc}^{\mathrm{a}}$ & $\begin{array}{l}13.67(s, 1 \mathrm{H}), 9.34(d, 1 \mathrm{H}), 9 \cdot 11(m, 1 \mathrm{H}), 8.86(d, 1 \mathrm{H}) 8.71(d, 1 \mathrm{H}), \\
\quad 8.06(m, 2 \mathrm{H}), 4.50(\mathrm{br}, 2 \mathrm{H})\end{array}$ \\
\hline ptzo $^{\mathrm{b}}$ & $9.13(d, 1 \mathrm{H}), 8.83(\mathrm{~m}, 2 \mathrm{H}), 8.74(\mathrm{~d}, 1 \mathrm{H}), 7.95(\mathrm{~m}, 1 \mathrm{H}), 7.74(\mathrm{~m}, 1 \mathrm{H})$ \\
\hline$\left[\mathrm{Ru}(\right.$ phen $\left.)(\text { ptzo })_{2}\right]\left(\mathrm{PF}_{6}\right)_{2}{ }^{\mathrm{b}}$ & $9.18(t, 2 \mathrm{H}), 8.81(m, 2 \mathrm{H}), 8.37(\mathrm{~s}, 2 \mathrm{H}), 8.22(\mathrm{~m}, 6 \mathrm{H}), 7.81(\mathrm{~m}, 6 \mathrm{H})$ \\
\hline$\left[\mathrm{Ru}(\mathrm{ptzo})_{3}\right]\left(\mathrm{PF}_{6}\right)_{2}{ }^{\mathrm{b}}$ & $\begin{array}{l}9.27(d d, 2 \mathrm{H}), 9 \cdot 03(d d, 2 \mathrm{H}), 8 \cdot 31(m, 4 \mathrm{H}), 8 \cdot 15(m, 4 \mathrm{H}) \\
\quad 7.82(m, 6 \mathrm{H})\end{array}$ \\
\hline
\end{tabular}

Spectra were recorded in ${ }^{\mathrm{a}} \mathrm{CDCl}_{3} ;{ }^{\mathrm{b}} \mathrm{DMSO}-d_{6}$

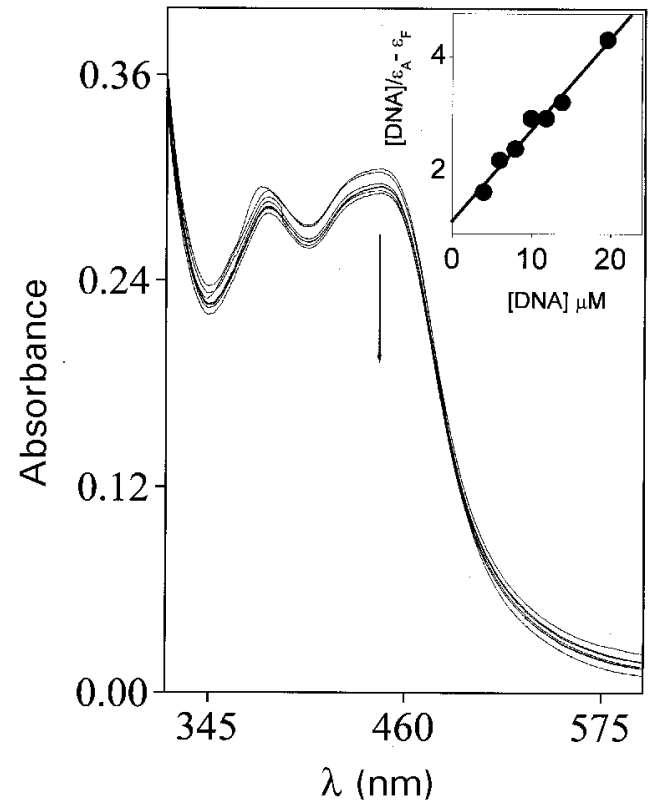

Figure 5. Results of absorption titration experiments carried out with $\left[\mathrm{Ru}(\right.$ phen $\left.)(\mathrm{ptzo})_{2}\right] \mathrm{Cl}_{2}$ in the presence of DNA. Inset illustrates the best fit of the binding data to (2) (see text for details).

\subsection{DNA binding}

Binding of the two new complexes synthesised in this study with CT DNA has been monitored by thermal denaturation as well as absorption and luminescence titration methods. The results obtained are summarised in this section, which also discusses aspects related to the ability of $\left[\mathrm{Ru}(\mathrm{phen})(\mathrm{ptzo})_{2}\right]^{2+}$ to act as a 'molecular light switch' for DNA.

Initial evidence for the interaction of the ruthenium(II) complexes with CT DNA came from the absorption titration experiment. Hypochromism as well as bathochromic shift in the MLCT peak maximum of $\left[\mathrm{Ru}(\mathrm{phen})(\mathrm{ptzo})_{2}\right]^{2+}$ was observed in the presence of increasing amounts of CT DNA in the UV-Vis spectrum which also revealed the presence of isosbestic points at $481 \mathrm{~nm}$ during this absorption titration experiment (see figure 5). The binding constant, $K_{b}$, for this interaction was estimated to be $1.42 \times$ 
$10^{5} \mathrm{M}^{-1}$ (see inset in figure 5 ). The corresponding $K_{b}$ for DNA binding by [Ru(ptzo $\left.)_{3}\right]^{2+}$ is $7.61 \times 10^{4} \mathrm{M}^{-1}$ as revealed by the results of similar set of experiments conducted with this tris-complex in the presence of DNA. The $K_{b}$ values for the two ptzo containing complexes are higher than that of $\left[\mathrm{Ru}(\text { phen })_{3}\right]^{2+}\left(K_{b}=7 \cdot 13 \times 10^{3} \mathrm{M}^{-1}\right)$. This fact coupled with the observation of hypochromism as well as bathochromic shift in the MLCT peak maxima of $\left[\mathrm{Ru}(\mathrm{phen})(\mathrm{ptzo})_{2}\right]^{2+}$ and $\left[\mathrm{Ru}(\mathrm{ptzo})_{3}\right]^{2+}$ suggest an intercalative mode of binding to DNA by both the complexes ${ }^{28}$.

Thermal denaturation experiments also revealed the intercalation of these new ruthenium(II) complexes with DNA. CT DNA was seen to melt at $61 \pm 1^{\circ} \mathrm{C}(2 \mathrm{mmol}$ $\mathrm{NaCl}, 1 \mathrm{mmol}$ phosphate) in the absence of any added complex. The $T_{m}$ of DNA is increased by $7 \pm 1^{\circ}$ in the presence of both $\left[\mathrm{Ru}(\mathrm{phen})(\mathrm{ptzo})_{2}\right]^{2+}$ and $\left[\mathrm{Ru}(\mathrm{ptzo})_{3}\right]^{2+}$ at [DNA nucleotide phosphate]/[complex] $=25$ (see figure 6 ). The $\sigma_{T}$ values of DNA were also increased by $4 \pm 1^{\circ}$ for both the complexes. The increase in $T_{m}$ and $\sigma_{T}$ of DNA can be interpreted in terms of the stabilization that results from the intercalation of these metal complexes with DNA ${ }^{28}$. The observations made during the absorption titration and thermal denaturation experiments are reminiscent of those reported earlier for various metallointercalators thus suggesting that $\left[\mathrm{Ru}(\mathrm{phen})(\mathrm{ptzo})_{2}\right]^{2+}$ and $\left[\mathrm{Ru}(\mathrm{ptzo})_{3}\right]^{2+}$ bind to DNA by an intercalative mode ${ }^{28-32}$.

Steady state emission spectra of a $10 \mu \mathrm{M}$ solution of $\left[\mathrm{Ru}(\mathrm{phen})(\mathrm{ptzo})_{2}\right]^{2+}$ in tris buffer $\left(5 \mathrm{mmol}\right.$ Tris, $50 \mathrm{mmol} \mathrm{NaCl}, p \mathrm{H} \mathrm{7.0)}$ ) showed extremely weak emission $\left(\phi<5 \times 10^{-4}\right)$. However, not only increase in the emission intensity ( $\sim 5$ times at the saturation point $)$ but also bathochromic shift (up to $54 \mathrm{~nm}$ !) was observed for this complex upon addition of CT DNA, figure 7. Binding constant, calculated using (3) $\left(1.52 \times 10^{5} \mathrm{M}^{-1}\right)$, agrees well

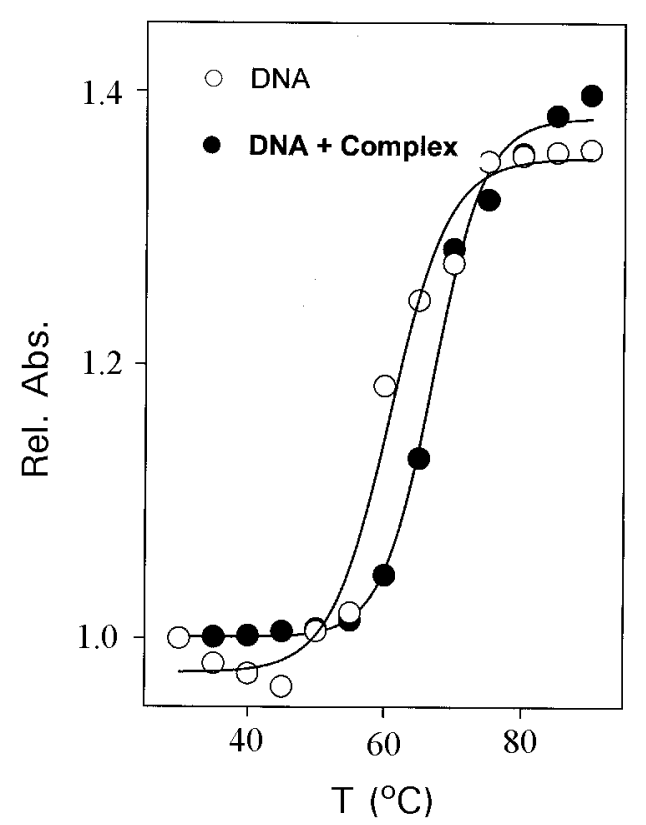

Figure 6. Thermal denaturation curves for CT DNA in the absence and presence of $\left[\mathrm{Ru}(\mathrm{ptzo})_{3}\right] \mathrm{Cl}_{2}$. 


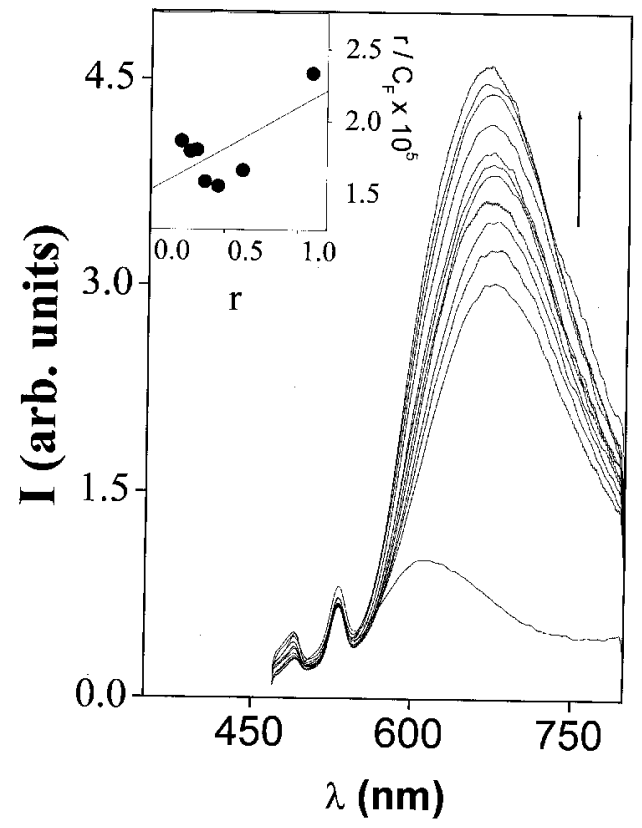

Figure 7. Luminescence enhancement observed for $\left[\mathrm{Ru}(\right.$ phen $\left.)(\mathrm{ptzo})_{2}\right] \mathrm{Cl}_{2}$ with increasing addition of CT DNA. Inset illustrates the best fit of the binding data to (3) (see text for details).

with the value obtained from the absorption titration experiment (vide supra). These emission characteristics are quite similar to that reported for $\left[\mathrm{Ru}(\mathrm{phen})_{2}(\mathrm{dppz})\right]^{2+}$ which is the classical example of a 'molecular light switch' for DNA ${ }^{3,7,33-35}$. They are also similar to those reported recently for $\left[\operatorname{Ru}(\text { phen })_{2}(\text { dicnq })\right]^{2+}$ and $\left[\operatorname{Ru}(\text { phen })(\text { dicnq })_{2}\right]^{2+}$, where dicnq is 6,7-dicyanodipyridoxoquinoxaline ${ }^{18}$. In the case of $\left[R u(p h e n)_{2}(\mathrm{dppz})\right]^{2+}$, the emission enhancement was ascribed to the protection of imine nitrogens from attack by water and a consequent decrease in nonradiative processes upon intercalation ${ }^{3,33-35}$. A similar mechanism was suggested for the other two complexes mentioned above. We believe that the case of $\left[\mathrm{Ru}(\mathrm{phen})(\mathrm{ptzo})_{2}\right]^{2+}$ discussed here is another example in this series of modified phen complexes in which intercalation brings about protection from water and hence decrease in the non-radiative rate constant. In support of this proposition, we note that the emission peak maxima of $\left[\mathrm{Ru}(\text { phen)(ptzo })_{2}\right]^{2+}$ in both DNA and in $\mathrm{CH}_{2} \mathrm{Cl}_{2}$ are comparable $(\sim 695 \mathrm{~nm})$. This observation lends credence to the above argument that intercalation of the complex positions the ptzo ligand in a more hydrophobic region devoid of water.

In summary, $\left[\mathrm{Ru}(\mathrm{phen})(\mathrm{ptzo})_{2}\right]^{2+}$ and $\left[\mathrm{Ru}(\mathrm{ptzo})_{3}\right]^{2+}$ have been synthesised and spectroscopically characterised. The interaction of these new complexes with DNA has been monitored by absorption and emission titration and thermal denaturation methods. $\left[\mathrm{Ru}(\mathrm{phen})(\mathrm{ptzo})_{2}\right]^{2+}$ was found to be a moderately efficient 'molecular light switch' for DNA. 


\section{Acknowledgements}

Financial support received from Department of Science and Technology for this work is gratefully acknowledged. SM and CVS thank University Grants Commission for fellowships.

\section{References}

1. Kaes C, Katz A, and Hosseini M W 2000 Chem. Rev. 1003553

2. Kelly S O and Barton J K 1999 In Metal ions in biological systems (eds) A Sigel and H Sigel (New York: Marcel Dekker) 39211

3. Erkkila K E, Odom D T and Barton J K 1999 Chem. Rev. 992777

4. JohannT W and Barton J K 1996 Philos. Trans. R. Soc. (London) 299354

5. Mesmaeker A K, Lecomte J P and Kelly J M 1996 Topics Curr. Chem. 25

6. Sigman D S, Mazumder A and Perrin D M 1993 Chem. Rev. 932295

7. Murphy C J and Barton J K 1993 Methods Enzymol. 226576

8. Pyle A M and Barton J K 1990 In Progress in inorganic chemistry: Bioinorganic chemistry (ed.) S J Lippard (New York: John Willey) 38413

9. Tysoe A A, Kopelman R and Schelzig D 1999 Inorg. Chem. 385196

10. Collins J G, Aldrich-Wright J R, Greguric I D and Pellegrini P A 1999 Inorg. Chem. 385502

11. Dixon D W, Thornton N B, Steullet V and Netzel T 1999 Inorg. Chem. 385526

12. Önfelt B, Lincoln P and Nordén B 1999 J. Am. Chem. Soc. 12110846

13. Albano G, Besler P, De Cola L and Gandolfi M T 1999 Chem. Commun. 1171

14. Hillman R E, Dandliker P J and Barton J K 1997 Angew. Chem., Int. Ed. Engl. 362714

15. Arounaguiri A and Maiya B G 1996 Inorg. Chem. 354267

16. Arounaguiri A and Maiya B G 1999 Inorg. Chem. 38842

17. Ambroise A and Maiya B G 2000 Inorg. Chem. 394256

18. Ambroise A and Maiya B G 2000 Inorg. Chem. 394264

19. Perrin D D, Armarego W L F and Perrin D R 1986 Purification of laboratory chemicals (Oxford: Pergamon)

20. Yamada M, Tanaka Y, Yoshimoto Y, Kuroda S and Shimao I 1992 Bull. Chem. Soc. Jpn. 65 1006

21. Krause R A 1997 Inorg. Chim. Acta 22209

22. Zou X-H, Li H, Yang G, Deng H, Liu J, Li R H, Hang Q-L, Xiong Y and Ji L-N 2001 Inorg. Chem. 407091

23. Juris A, Balzani V, Brigelletti F, Campagna S, Belser P and Zelewsky A V 1998 Coord. Chem. Rev. 8485

24. Lackowwicz J R 1983 Principles of fluorescence spectroscopy (New York: Plenum)

25. Reichmann M E, Rice S A, Thomas C A and Doty P 1954 J. Am. Chem. Soc. 763047

26. Wolfe A, Shimer G H and Meehan T 1987 Biochemistry 266392

27. Kumar C V and Asuncion E H 1993 J. Am. Chem. Soc. 1158547

28. Long E C and Barton J K 1990 Acc. Chem. Res. 23273

29. Kelly J M, Tossi A B, McConnell D J and OhUigin C 1985 Nucleic Acids Res. 136017

30. Satyanarayana S, Dabrowiak J C and Chaires J B 1992 Biochemistry 319319

31. Neyhart G A, Grover N, Smith S R, Kalsbeck W A, Fairley T A, Cory M and Thorp HH 1993 J. Am. Chem. Soc. 1154423

32. Hartshorn R M and Barton J K 1992 J. Am. Chem. Soc. 1145919

33. Friedman A E, Chambron J C, Sauvage J P, Turro N J and Barton J K 1990 J.Am.Chem. Soc. 1124960

34. Friedman A M, Kumar C V, Turro N J and Barton J K 1991 Nucleic Acid. Res. 192595

35. Olson E J C, Hu D, Hormann A, Jonkman A M, Arkin M R, Stemp E D A, Barton J K and Barbara P F 1997 J. Am. Chem. Soc. 11911458 (and references therein) 